\title{
Lesson Study Based on Local Wisdom and Entrepreneurship of Play and Games Subject
}

\author{
Mutiara Magta \\ Early Childhood Education Dept. \\ Universitas Pendidikan Ganesha \\ Singaraja, Indonesia \\ mutiara.magta@undiksha.ac.id
}

\begin{abstract}
The implementation of Lesson study in Faculty of Education, Ganesha University of Education is aimed to improve all the learning quality. The lesson study executed for 1 period toward Play and Games subject in Early Childhood Education, Faculty of Education. This lesson involved eleven actors they are 9 observers, a model lecturer and one as the lecturer's partner. Lesson study applied through 3 steps, they are the plan, do and see/reflection. The implementation result shows that (a) it increases the lecturer's performance in holding the pedagogy, professional, social, and personal competence as they practicing at classes, they become more careful in learning plan arrangement, more ready and overcome the learning process, and escalate their cooperation; (b) produce the learning quality that has local wisdom values; (c) improve the entrepreneurship of the student.
\end{abstract}

\section{Keywords - lesson study, learning quality, professionalism}

\section{INTRODUCTION}

Lecturers are one of the main needs for a university. They are like a moving machine for all the scientific and academic activities [1]. The university as if a body then the lecturer is the heart. This means that they really have an important position in education and graduates quality. Barakat [2] says that a good quality education program needs a good quality lecturer. By that, the university can arrange the most modern programs and curriculums to guarantee high-quality graduates.

The Lesson study program applied by the Faculty of Education, Ganesha University of Education is one of the efforts to increase the lecturer quality in teaching implied to learning quality escalation. Lesson study is a study activity on the implementation of learning carried out by lecturers. Lesson study began in Japan with practice-based to develop the ability of lecturer professionalism. Catherine [3] explains how this Lesson study contributes toward the lecturer professionalism improvement by describing 8 the lecturer's experiences. Lesson Study enables them to 1) think accurately about the learning visions, main substance, and field of study learning, 2) review and improve the best possible learning, 3) add the knowledge about the applied main substance, 4) think deeply about the achieved longterm visions related to student, 5) plan the learning collaboratively, 6) review the ways, learning process and student's behavior carefully, 7) improve the appropriate pedagogy knowledge for the student, and 8) see the learning result through the students and colleagues' view.

The using of lesson study during the learning process helps the lecturer to improve student skill in planning, executing and evaluating the applied learning process. Lecturer professionalism in teaching at class has influenced to learning quality escalation in the end. This lesson study is based on local pearls of wisdom and entrepreneurship so the learning process can be more directed. The study uses local pearls of wisdom so this country's cultural values can be maintained, while the applied entrepreneurship is an effort to achieve adding competencies for the Early Childhood Education graduates, as the curriculum stated that they can manage and his the ability to be an entrepreneur.

The other baseline of this entrepreneurship reason is caused by the increase of unemployment in Indonesia. In 2007, the educated unemployment reached 1.4 million. According to Ciputra [4], there are 3 former factors of entrepreneurship, they are physical, environment and practice. In this practice factor, the education role plays significantly. Therefore, the aim of the learning process through this lesson study based on local pearls of wisdom and entrepreneurship can be implied toward learning quality escalation, especially for Play and Games subject.

\section{METHOD}

The Lesson study applied in Play and Games subject by one period in six meetings. Each meeting includes the steps of the plan, do, and see/reflection. The Lesson study applied in Play and Games subject by one period in 6 meetings. Each meeting includes the steps of the plan, do, and see/reflection. Plan and do steps involve two lecturers as the teaching team, one of them is a model lecturer. The observers are from Early Childhood Education and other study lecturers. This study also involves the representation from kindergarten teacher to maximize the learning quality. All observers are nine. Observers and model lecturer gather to reflect and give opinions about the flaws in learning, describe the student behavior during the learning process, and show the model lecturer's power as motivation for others. The data collected based on planning activities, documentation, and reflection. Lesson study data analysis applied in narrative descriptive explanation. Plan and do steps involve two lecturers as the teaching team, one of them is a model lecturer. The observers are from Early Childhood Education and other study lecturers. This study also involves the representation from kindergarten teacher to maximize the learning quality. All observers are nine. Observers and model lecturer gather to reflect and give opinions about the flaws in learning, describe the student behavior during the learning process, and show the model lecturer's power as motivation for others. The data collected based on planning activities, documentation, and reflection. Lesson study data analysis applied in narrative descriptive explanation. 


\section{RESULT AND DISCUSSION}

The applied lesson study in Play and Games subject produces achievements, they are: (1) escalation of lecturer performance (2) escalation of learning quality includes local pearls of wisdom (3) improvement of the student's entrepreneur character.

Below is the result explanation and discussion of learning study in Play and Games subject:

\section{A. Escalation of Lecturer Performance Has An Impact Toward Learning Quality}

According to Undang-Undang RI 2005 Number 14 about teacher and lecturer, it says that teacher and lecturer have to coerce four competencies; pedagogy, professional, social, and personality competency. Lecturers have to show all the competencies professionally. They can show their professionalism and practice better through the Lesson study.

\section{1) Lecturer's accuracy on lesson plan implementation}

The lesson plan has the vital role in learning implementation includes the materials given to the students. Sanjaya [5] states that the planning of learning is a decision making of thinking result rationally about specific learning goals, also some activities as it's achievement effort by using all the capabilities and learning resources. As the rationally thinking result, lesson plan arrangement in Play and Games subject requires accuracy. This Lesson study helps the lecturer to minimize their limit in plan arrangement. The Lesson study gives chances to the model lecturer to form a team, as a teacher or observer. These 2 teams give helping opinions in lesson plan arrangement. Model lecturer and the team discuss the goals carefully, substantial, learning strategy and suitable applied media in the learning process, especially in Play and Games subject.

The first form of this planning is not happening perfectly. After the first open class, model lecturer and the team get used to discuss about the next open class planning, based on the observer's explanation so they can consider rational decisions toward learning obstacles Model lecturer and the team try accurately as possible to avoid mistakes of former learning so the lesson plan quality can be improved better. An example from the lesson plan arrangement by using educative playing equipment is the model lecturer talks around and not using the real equipment. The observer finds out the negative response from a student; it is hard to get the illustration of the educative playing equipment. These facts are described by the observer team toward the model lecturer so they can pay attention closely to the next lesson plan arrangement.

The eminence of this learning quality plan is in line with Sagala [6] saying that the goal is not just the basic principal control, but also a positive mind improvement toward learning process, examine and find the learning problemsolving. The importance of accuracy in lesson plan arrangement is implied toward the whole learning implementation.

2) Readiness and lecturer mastery toward learning process implementation

Lecturer professionalism reflected on how mastering the class. This class mastery includes the applied substance, student character, learning theories, educative learning principals, learning strategies and media. Those are part of a lecturer's pedagogy competence.

Through the reflection, model lecturers enclose all the opinions from the teams and arrange the plan, so that they can practice their best pedagogy competence. For example, the model lecturer facilitates the class by using more playing media for a student as the observer suggested. This model lecturer teaches the student with the substance, strategies, and media as planned before. They also motivate the student by giving the reward to the active student, reminding the passive ones or guiding them in needs. This is as well as what Takahashi and Yoshida [7] say that the lesson study gives chance to the teacher to understand the education opinions by practice, change the teaching point of view, consider the student's point of view about the learning, and get support from colleagues.

Based on the lesson study on the implementation step, model lecturer's pedagogy competence of Play and Games subject is increased, in line with the research by Murtisal, et al [8] says that Biology teacher's pedagogy competence goes well and applied successfully because of lesson study implementation. The research result of Listyani [9] says so, that lesson study implementation in teacher's pedagogy competence escalation can help them to organize the class better, plan the learning and improve the media creatively so the student has a good attention and participate actively.

\section{3) Cooperation among colleagues}

The characteristic of this lesson study implementation is people involvement. The model lecturer is one but every step of lesson study implementation needs more people. For example, the plan needs 2 lecturers to discuss, the do needs observer team and teaching team, also the reflection needs all team.

The process of each step includes discussing the substance, strategies, media, and so on. The learning implementation invites other lecturers to be the observer team and not just the teaching team. Then, the observer team gives feedback to the model lecturer includes good points, constructive criticisms and also helps them to describe the learning process. This cooperation among colleagues is needed because when they work alone, they tend to arrange boredom learning because there is no other opinion from colleagues.

A lecturer should have the social and personal competence to interact with others. Undang-undang Guru dan Dosen 2005, Number 14 Tahun 2005 states that personality is "a strong ability, having good manner, wise, commanding and be an example for the student. Surya [10] says that social competence is competence a person should have to interact with others. This competence includes social interaction skill and social responsibility consummation.

As the professionalism and pedagogy competence, the lesson study gives space for the lecturer to show and escalate their personality and social competence. This action will improve their performance and student learning quality. The condition has the same line with Sukirman's [11] states that lesson study is a teacher's training model reviewed by collaborative and sustainable learning, based on colleagueship principals that help one to each other to build the learning community. As the research of Sudarlan and Rifadin [12] says that personality and social competence impacts to lecturer's performance significantly. 


\section{B. The Escalation of A Meaningful Learning Quality Based on Local Pearls of Wisdom}

A good learning process is a meaningful learning for a student, a learning that gives them education and not just transfers them the knowledge. Through this lesson study based on local wisdom, the lecturer will always involve cultural virtues in the learning process. In the traditional games part of Play and Games subject, the lecturer asks the student to analyze the virtues of each traditional games especially the Bali's.

According to Dewantara [13], traditional games reflects the life and customs of a community. Another meaning says that traditional games are cultural virtues games contains a must preserved heritages. In the first open class, the student just discusses the difference between traditional and modern games. The second open class will invite them to practice the traditional games directly so they can understand its advantages, especially for children's basic competence development.

One of the applied traditional games is "Megoakgoakan", tells about Panji Sakti's story defeated the Blambangan kingdom. The games rule is they make the circle line, 2 of them play a role as goak (snake) and they chase each other inside the line. Then the model lecturer asks the student to find the history of the games and analyze the good points from its history and movements. This is suggested so the student can teach the games to their student, too. The third open class directs the student to improve and create a traditional game based on the children's development goals to be achieved.

The result is the student becomes more enthusiastic to learn, actively ask and give their opinions. The discussions conduct meaningful ideas for children's educative improvement. They are (1) make the traditional games as a media for character building, (2) modify the traditional games to an art exhibition, and so on.

\section{The Student's Entrepreneurship Character Improvement}

The character building is something comes up for a long time in Indonesia. Dewantara [13] states that education is efforts to build the character, intellect, and physic. Character building is an important part of education substance in Indonesia. Ir. Soekarno as the first president of Indonesia [14] underlines that Indonesia has to built above the character building so it can be a huge, progressive, victorious, and dignified country. According to Sudrajat [15] character education is important for human life, so the role played by the education world must not only show moral knowledge but also love and be willing to do moral actions.

As the knowledge of the importance of character building, Early Childhood Education lecturers are charged with the responsibility to help the student in growing entrepreneurship character on themselves, in accordance with the adding competence for graduates beside the teacher and manager. the importance of entrepreneurship is caused by a large number of educated unemployed so that the character of entrepreneurship needs to be incorporated into the curriculum. other than that if students have the character of entrepreneurship can increase the interest of students to choose entrepreneurship as an option career besides choice as an employee. This is the main reason for this lesson study based on entrepreneurship. The lecturer tries to determine an inspired learning for the student to create products and how to market them. The entrepreneurship character improvement needs opinions from teaching the team of the plan and the observer.

One of this entrepreneurship character improvement reflects on the fourth, the fifth and the sixth open class, so the lecturer asks the student to present their products such as educative playing equipment. The lecturer manages the exhibition where the student will present the products to the visitors (students from other classes), then they are pleased to visit and give the assessment. This learning process aims to grow the entrepreneurship character of the student by giving chances to create useful products for the community, also an experience of how to be a good entrepreneur, how to create and market the products. Some of their products are physic development monopoly, moral development snake and ladders, Uno cards for introducing animals, character building scrabble, and so on.

\section{CONCLUSION AND SUGGESTION}

The conclusion from research result and discussion is this lesson study helps the lecturer to escalate the learning quality of Play and Games subject. Each period reveals an escalation of every learning process. This escalation can be seen in (1) lecturer's professionalism on planning, implementation, evaluation, and cooperation process among colleagues as pedagogy, professionalism, social, and personality competence (2) the applied learning gives the student a meaningful learning because it involves cultural virtues studied and improved by themselves (3) the learning builds and motivates the student to have better manners, they are a creative and innovative entrepreneur character.

Based on that explanation, the suggestions are : (1) model lecturer preserves good things to emulated and improves opinions from the observer team in the next learning (2) other lecturers who has no chances yet to be model lecturer before are pleased to offer their class confidently so they have experiences beside of being the observer team (3) the experienced lesson study lecturers are invited to help the other to apply this lesson study through Community Service (Pengabdian kepada Masyarakat/PKM).

\section{REFERENCES}

[1] Ammar, H. 1996. Al-Jami'ah Bayn al-Risalah wa al-Muassasah. Cairo: al-Dar al-'Arabiyyah li al-Kitab.

[2] Barakat, M. A. 1998. al-Tathwir al-Mahniy li A'dla'i Hay'at alTadris. Tunis: al-Munazhzhamah al-'Arabiyah li al-Tarbiyah.

[3] Catherine, L. 2004. Does Lesson Study Have a Future in the United States. Online: http://www. sowi-online. de/journal/20041/lesson_lewis. htm.

[4] Ciputra, I. 2009. Quantum Leap Entrepreneurship Mengubah Masa Depan Bangsa dan Masa Depan Anda. Jakarta: Elex Media Computindo. 2009.

[5] Sanjaya, Wina. 2008. Perencanaan dan Desain Sistem Pembelajaran. Jakarta: Kencana.

[6] Sagala, G. 2003. The relationship between cost of capital and leverage for companies quoted on the Nairobi Stock Exchange (Doctoral dissertation).

[7] Takahashi, A., \& Yoshida, M. 2004. Lesson-study communities. Teaching children mathematics, 10(9), 436-437.

[8] Murtisal, E., Nurmaliah, C., \& Safrida, S. 2017. Implementasi Pembelajaran Berbasis Lesson Study Terhadap Kompetensi Pedagogik dan Keterampilan Proses Sains Guru Biologi SMA Negeri 11 dan MA Negeri 3 Kota Banda Aceh. BIOTIK: Jurnal Ilmiah Biologi Teknologi dan Kependidikan, 4(1), 81-94. 
[9] Listyani, E., Djamilah, B. W., Mathilda, S., Elly, A., and Kana, H. Development of Mathematics High School Teacher's Competence Through Lesson Study (A Case Study in Yogyakarta, Indonesia). International Conference on Lesson Study (Lesson Study: a Challenge for Quality Improvement in Education, July 31 - August 1, 2008.

[10] Surya, Muhammad. 2003. Psikologi Pembelajaran dan Pengajaran. Bandung: Yayasan Bhakti Winaya.

[11] Agoestanto, A., Kurniasih, A. W., Zahid, M. Z., \& Mulyono, M. 2017. Enhancement of Lecturer Professionalism using Lesson Study Approach for Curriculum Review of Mathematics 1. Unnes Journal of Mathematics Education, 6(3)
[12] Sudarlan, S., \& Rifadin, R. 2016. Pengaruh Kompetensi Sosial Dan Kompetensi Kepribadian Terhadap Kinerja Dosen Di Jurusan Akuntansi Politeknik Negeri Samarinda. Jurnal Eksis, 12(1).

[13] Dewantara, Ki Hajar. Pendidikan \& Kebudayaan. Yogyakarta: Majelis Luhur Persatuan Taman Siswa. 1977.

[14] Hariyanto, M. S. 2011. Konsep dan Model Pendidikan Karakter. Bandung: PT RemajaRosdakarya.

[15] Sudrajat, A. 2011. Mengapa Pendidikan Karakter?. Jurnal Pendidikan Karakter, 1(1). 